
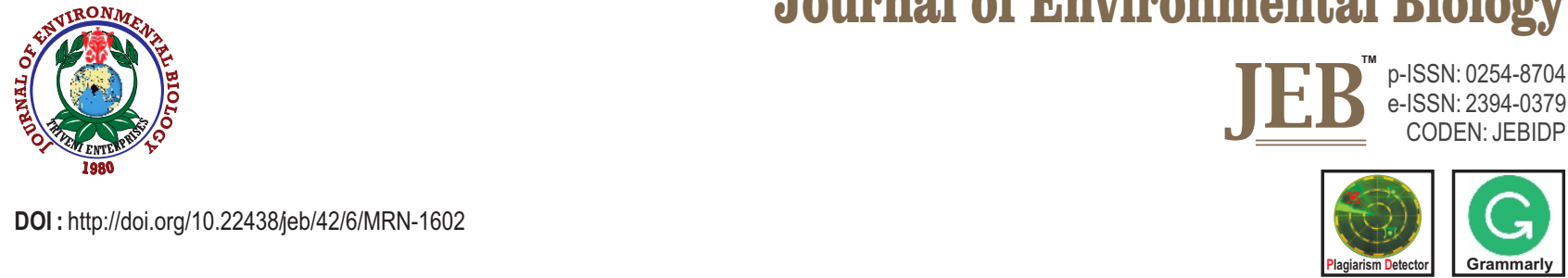

\title{
Influence of pre-harvest fruit bagging and plant cover on peel colour, physical appearance and quality traits of pomegranate fruits in arid conditions
}

\author{
A. Singh, H.M. Meena, P. Santra, P.R. Meghwal and P. Kumar \\ ICAR-Central Arid Zone Research Institute, Jodhpur - 342 003, India \\ *Corresponding Author Email : akath2005@yahoo.co.in
}

\section{Abstract}

Aim: To study the influence of fruit bagging and plant cover on microclimate modification and its role on external quality traits and physico-chemical fruit characteristics of pomegranate $c v$. Bhagwa in arid conditions.

Methodology: Fruits bagging was done with single layer bags of news paper (NP), brown paper (BP), white parchment paper (PP), non-woven polypropylene (NWP), complete plant covering with non-woven polypropylene (CNWP), and un-bagged with no cover was kept as control. Bagging was done 60 days after fruit set and continued until harvest, each year.

Results: Bagging and plant covering modified the microenvironment which positively influenced the fruit development. Among the bags, inside air temperature was higher in $\mathrm{BP}$ followed by NP, PP and NWP, while RH was higher in PP. PP bags was most effective for the development of attractive red peel color ( $\mathrm{a}^{*}$ value $=44.4)$ followed by NWP $\left(a^{*}\right.$ value $=$ 39.6 ) or CNWP (a* value $=36.6$ ). All four bags were able to check thrips incidence completely, while PP bagging provided physical scratches or fungal spot free fruits. Physical attributes of fruits including fruit weight, aril weight, peel thickness and juice content were considerably affected.

Interpretation: Fruit bagging or plant covering is simple, cost-effective and eco- friendly way to produce quality safe pomegranate fruits under adverse climatic conditions of arid regions.

Key words: Bagging, Eco-friendly material, Microclimate, Peel colour, Pomegranate

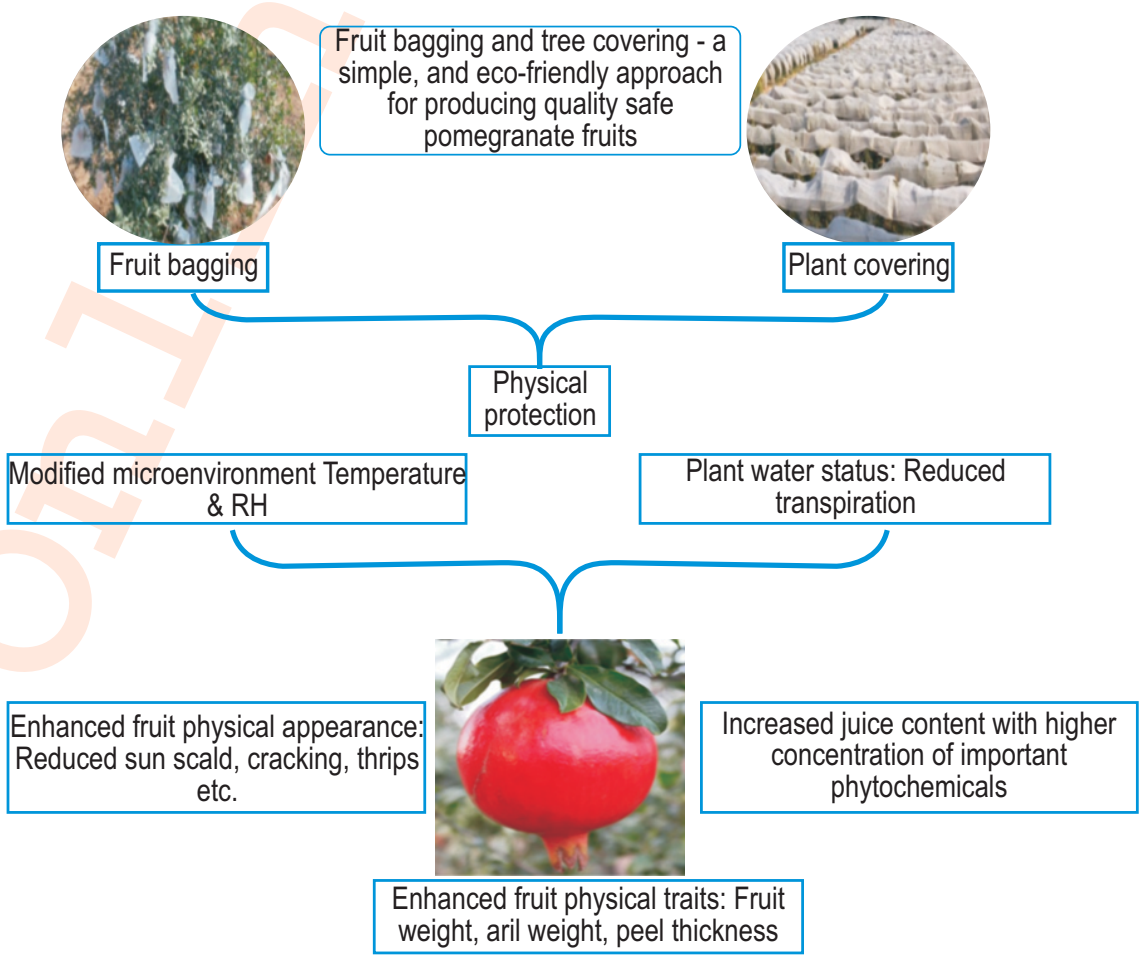

How to cite : Singh,A., H.M. Meena, P. Santra, P.R. Meghwal and P. Kumar: Influence of pre-harvest fruit bagging and plant cover on peel colour, physical appearance and quality traits of pomegranate fruits in arid conditions. J. Environ. Biol., 42, 1560-1566 (2021). 


\section{Introduction}

Pomegranate (Punica granatum L., family Punicaceae) is considered as one of the most important fruit crops of arid and semi-arid regions of the world (Babu, 2010). The demand of pomegranate has increased worldwide owing to its immense medicinal and therapeutic values (Supe and Saithwal, 2016; Gumienna et al., 2016). There has been enormous increase in area, production and export of pomegranate across the world over the past decades. Globally, India is the largest producer of pomegranate both in area (2.46 lakh ha) and production (28.65 lakh tons) (NHB, 2018). Versatile adaptability, short-term high economic return and high demand for export are the major driving forces for increased area under pomegranate cultivation in semiarid and arid regions of India (Singh et al., 2019a). The export of pomegranate from India has increased from merely 35 thousand tons in 2012-13 to 67.89 thousand tons in 2018-19 with continuous increase in export earnings from 2012-13 onwards (NHB, 2018). These trends depict a high amenability in supplydemand of Indian pomegranate in international market with higher price. However, the increasing competition between pomegranate growing countries to supply high quality standard fruits is a major concern. Glossy attractive red colored fruits, which are free from pesticide residues, physical injuries of marks and scratches, disease stains etc., are preferred in the International market (Gadze et al., 2012). Cultivar, growing environments and crop management practices are certain preharvest factors which determine the quality of fruit (Sharma et al., 2014). In India, the cultivar 'Bhagwa' is the preferred cultivar grown in about $90 \%$ area under pomegranate cultivation because of attractive appearance of the fruits like round and globosely shape, dark rose red colour of fruits and aril, soft seeds with good taste and aroma (Ram Chandra et al., 2011).

Under arid conditions of Rajasthan, pomegranate crop is regulated for mrig bahar (July-August to January-March). However, the prevailing environments during fruit development often affect the quality of fruits. Intense solar radiations, high wind speed and sharp fluctuations in day and night temperatures are prevalent weather conditions, which often distress the fruit quality. As a result, there are occurrences of poor colour development, sunscald and fruit cracking in pomegranate (Singh et al., 2019b). Poor quality fruits ultimately affect the marketability of fruits. High proportion of locally produced fruits is consumed in local markets or inter-state markets whereas a few proportions are exported to Gulf and neighboring countries. However, the avenues have been opened to export pomegranate fruits from India to European Union countries and China. In order to fetch good price of fruits in domestic as well as international markets, it is desirable to produce good quality fruits under prevailing weather conditions of arid regions, which may be achieved by adopting good management practices in the fruit orchard (Amarante et al., 2002). Among various strategies, pre-harvest fruit bagging with different bagging materials and plant covering as a whole has emerged as one of the best eco-friendly approaches in different parts of the world for enhancing marketability of good fruit quality in different fruit crops e.g. apple, peach, pear, grapes etc. (Sharma et al., 2014; Zhang et al., 2015). Bagging technique involves covering of individual fruit or individual plant or complete row of plants for a specific period to obtain desired results. It is a physical protection that can improve the appearance and quality of fruit by avoiding physiological and pathological injuries and by modifying the micro-climate inside covered conditions (Sharma et al., 2013; Grinan et al., 2018; Hameidi et al., 2019). Response of type and colour of bagging materials may differ with respect to growing environments and crop species (Asrey et al., 2019; Kim et al., 2010). However, the information on the effect of bagging on fruit quality of pomegranate is very limited. Therefore, a systematic study was undertaken on the effect of different types of bagging materials on peel colour, incidence of sun scald, fruit cracking and other important quality attributes of pomegranate $\mathrm{cv}$. Bhagwa.

\section{Materials and Methods}

Plant materials and experimental design: The study was conducted during two successive fruiting seasons of pomegranate (Mrig bahar) during 2018-19 and 2019-20 at ICARCentral Arid Zone Research Institute, Jodhpur Rajasthan India under ferti-drip system of irrigation. The weather conditions of the site is very hot $\left(\sim 45-48^{\circ} \mathrm{C}\right)$ and dry (relative humidity ranges from $35 \%$ to $70 \%$ ) during summer (April-June) and cool $\left(\sim 4.1-14^{\circ} \mathrm{C}\right.$ ) during winter months (December-February) along with very high rate of evaporation throughout the year with peak during summer ( 3.5 to $13.5 \mathrm{~mm}$ day ${ }^{-1}$ ). The region is characterized by a monsoon climate with the wet season receiving $95 \%$ of total annual rainfall during July to September.

Fifty four pomegranate plants $\mathrm{cv}$. Bhagwa of uniform age and vigour, established at $4 \mathrm{~m} \times 3.5 \mathrm{~m}$ spacing, were used as experimental materials for this study. All plants received uniform cultural practices. The experiment was laid out in completely randomized block design. During both the seasons, healthy and uniform size fruits were covered with $15 \mathrm{~cm} \times 20 \mathrm{~cm}$ single layer bags of four bagging materials: non-woven polypropylene (NWP) (17gsm); news paper (NP), brown paper (BP), and white parchment paper (PP). Apart from the individual fruit bagging, another treatment with full cover of plant with non-woven polypropylene fabric (17gsm) (CNWP) was also included in the experiments whereas un-bagged fruits were taken as control. Bagging and plant covering was done at 60 days after fruit set and continued until harvest during each year. Bags were minutely perforated ( $\sim-8$ openings) with fine needle to provide air exchange. The mouth of bags was closed with staple pins to prevent the entry of insect pests. Each treatment was replicated thrice having three plants per replications and bagging was done on ten fruits in each selected plant. In CNWP treatment, $7.5 \mathrm{~m}^{2}$ 
non-woven polypropylene sheets were used to cover the whole individual plant, which were replicated thrice.

Meteorological observations : Five bags in each replication were randomly selected to record the meteorological observations on air temperature and relative humidity at an interval of 15 days inside the bagging condition, covered condition as well as in open sun during 12:00-13:00 hr using temperature sensors and Assmman psychrometer (Hisamatsu make, Model MR-58), respectively. Photosynthetically active radiation was measured in all the treatments and control under clear sky condition during $12.00-13.00 \mathrm{hr}$ using line quantum sensor (Make: Apogee, MQ-301, Series\#1178). The transmittance of light through bagging material used in this study was about $84,16,8$ and $56 \%$, respectively for NWP, NP, BP and PP.

Estimation of external fruit quality attributes: Observations on sun scald, fruit cracking, thrips injuries, fungal spots and physical injuries on fruits were recorded using selected fruits of each plant during each picking. Affected fruits with individual maladies were sorted out and counted separately and presented in per cent.

Estimation of morphometric quality attributes of fruits: Total 180 well matured fruits were harvested (average TSS $16.0^{\circ}$ Brix) for recording the observations on physico-chemical attributes. Out of these, ten randomly selected fruits were taken for recording observations on physical properties viz. fruit size, fruit weight, aril weight, peel weight, peel thickness using standard methods and average of these was taken for further statistical analyses. Fruit juice was extracted using mechanical juicer and grinder followed by squeezing using muslin cloth and the fruit juice content was expressed as per cent on fresh fruit weight basis.

Estimation of chemical quality attributes of fruits: TSS was determined using digital hand held refractometer (Model: Brix 54, Bellingham + Stanley Ltd., UK), which was calibrated using distilled water before estimation. The acidity and total sugars of fruit juice was determined following the method of Ranganna (2017). Ascorbic acid content was determined using 2, 6dichlorophenol indophenols dye method (A.O.A.C., 2000). The amount of ascorbic acid was expressed as $\mathrm{mg}$ ascorbic acid 100 $\mathrm{ml}^{-1}$ of fruit juice. Total anthocyanin content of fruit juice was determined following the method of Ranganna (2017). The absorbance of extracted supernatant was measured at $510 \mathrm{~nm}$ using UV-VIS spectrophotometer (Model: UV mini-1240 and make: Shimadzu, Japan). Total anthocyanin concentration was expressed as mg100 $\mathrm{ml}^{-1}$ of fruit juice. The amount of total phenolics in fruit juice extracts was determined by Folin-Ciocalteu assay as described by Singleton et al. (1999) and expressed as mg catechol equivalents (CtE) $100 \mathrm{ml}^{-1}$ d.wt.

Estimation of fruit colour : Fruits colour was measured using colorimeter (Model: WR-18, Make:FRU China) at top, middle and bottom portion of the fruits and average colour was expressed as per CIE L*a*B* colour space model. In the CIEL*a*b* model, $L^{*}$ value of 0 represents complete dark and 100 represents complete white, negative $a^{*}$ values represents greenness and positive $a^{*}$ value represents redness and negative $b^{*}$ value represents blueness and positive $b^{*}$ value represents yellowness. The colour intensity, chroma $(\mathrm{C})$ was further calculated.

Statistical analyses : The experiment was conducted in a completely randomized block design (CRD). Data recorded from each treatment under different parameters were subjected to analysis of variance (ANOVA). Mean comparison were performed using LSD test $(p<0.05)$. All analyses were performed using SAS 9.2 (SAS Institute, Cary, NC, USA).

\section{Results and Discussion}

The modification caused by covering and bagging provided a favourable inner microclimate which resulted in unblemished, uniform, and intense colour development in pomegranate fruits. This was evident by lower air temperature and higher relative humidity in row and individual covering than those in ambient condition. While fruits were covered in bags, there was higher air temperature and relative humidity than their respective values recorded in ambient condition (Table 1). Among the bags, $2.1^{\circ} \mathrm{C}$ higher air temperature was recorded in brown paper bags followed by news paper bag $\left(1.8^{\circ} \mathrm{C}\right)$, parchment bag $\left(1.2^{\circ} \mathrm{C}\right)$ and non-woven polypropylene bag $\left(0.8^{\circ} \mathrm{C}\right)$ as compared to open ambient conditions during 2018-2019. While, relative humidity was higher $(7.8 \%)$ in parchment paper bag followed by news paper bag (5.1\%), non-woven polypropylene bag (4.0\%) and brown paper bag (3.5\%) than ambient one. During 20192020 fruiting season, variations in air temperature showed similar trend and followed the order of brown paper bag $\left(4.0^{\circ} \mathrm{C}\right)>$ news paper bags $\left(3.6^{\circ} \mathrm{C}\right)>$ parchment paper bag $\left(2.7^{\circ} \mathrm{C}\right)$ and nonwoven fabric bag $\left(1.6^{\circ} \mathrm{C}\right)$, while relative humidity was low in bags compared to ambient conditions, except for white parchment bag.

As far as plant covering with non-woven polypropylene is concerned, in contrast to air temperature, relative humidity was significantly altered as compared to open conditions. Previous studies on similar line conducted by various workers concluded that bagging with different materials were able to modify the micro-environment inside bags during fruit growth and development. These modifications showed positive effect on quality and chemical composition of different fruits (Kim et al., 2003; Yang et al., 2009; Xu et al., 2010 ). Bagging maintained a high relative humidity around the fruit, resulting in less water loss and increase in cell turgor pressure (Zhang et al., 2015).

Among covering materials, bagging with parchment paper and brown paper bags were found most efficient in percent checking of sun scald disorders in fruit, while non-woven 
Table 1: Effect of fruit bagging and plant covers on external quality attributes of pomegranate cv. Bhagwa in arid conditions during 2018-2020

\begin{tabular}{lllll}
\hline Fruit bagging treatments & Sun scald $(\%)$ & Cracking $(\%)$ & Thrips injuries $(\%)$ & Fungal spots $(\%)$ \\
\hline NWP & $4.5^{\mathrm{a}}$ & $12.5^{\mathrm{a}}$ & 0 & $4.5^{\mathrm{a}}$ \\
NP & $10.0^{\mathrm{b}}$ & $17.8^{\mathrm{b}}$ & 0 & $3.80^{\mathrm{a}}$ \\
BP & 0 & $19.2^{\mathrm{b}}$ & 0 & $5.35^{\mathrm{a}}$ \\
PP & 0 & $10.5^{\mathrm{a}}$ & 0 & 0 \\
CNWP & $5.5^{\mathrm{a}}$ & $14.8^{\mathrm{c}}$ & $5.6^{\mathrm{a}}$ & $8.5^{\mathrm{b}}$ \\
Control & $21.8^{\mathrm{c}}$ & $28.3^{\mathrm{d}}$ & $9.3^{\mathrm{b}}$ & $13.5^{\mathrm{c}}$ \\
\hline
\end{tabular}

(Super scripted letters above values represents similarity and dissimilarity; values with similar letters are statistically similar whereas values with dissimilar letters are statistically dissimilar); NWP- Non-woven poly propylene, NP- News paper, BP- Brown paper, PP-White orchment paper, CNWPPlant covering with non-woven polypropylene fabrics

polypropylene bags and row covering showed only nominal incidence as compared to un-bagged fruits $(21.8 \%)$ (Table 1). Parchment paper and non-woven polypropylene bags were found most effective in minimizing fruit cracking. Irrespective of materials, the bagging technique totally checked the incidence of thrips, and white parchment bagging provided fruits without any physical scratches or fungal spots. Bagging and plant covering provides a physical protection from direct sun exposure, optimize physiological process, and changes micro-climate inside covering, besides lowering pathological injuries (Sharma et al., 2013, Sarkomi et al., 2019). Han et al. (2002) noted that the temperature inside the bag was correlated with light reflectance, absorbance and transmittance, and air permeability of the bag used. Higher fruit temperature along with direct sun exposure causes excess sun burning (Grinan et al., 2018). Results of present study regarding minimum sun scalding in bagged fruits are supported by data recorded on PAR and relative humidity which was in optimum range. As evident by data contained in Fig. 1 and 2 , bagged fruits maintained optimum temperature and high relative humidity vis-a-vis escapes from impact of direct strong and hot winds on skin of fruit and, therefore, can be effective in reducing cracking, and also preventing other disorders. Following bagging, earlier workers have also reported reduction in sun burning, fruit cracking and insect and physical injuries in pomegranate (Yuan et al., 2012; Grinan et al., 2018; Asrey et al., 2019), apple (Sharma et al., 2014) and longan (Yang etal. 2009).

Results of the present study revealed that all four bagging techniques and plant covering significantly influenced peel colour of pomegranate fruit as compared to un-bagged ( $a^{*}$ value $=28.1$ ) (Table 2). Bagging with white parchment paper bags resulted in the development of more attractive red peel color ( $a^{*}$ value $=$ 44.4), followed by non-woven polypropylene bagging or row covering. Chroma value $\left(C^{*}\right)$ which indicates colour intensity also followed similar pattern. Though colour variation $\left(L^{*} a^{*}, b^{*}\right)$ is principal character of genetic make-up of a variety, but the intensity and brightness are affected by agronomic practices within the cultivars, and it is clearly and significantly visible in the present study. The results of different bags on fruit peel colour may be due to difference in the light reflectance, absorbance, or

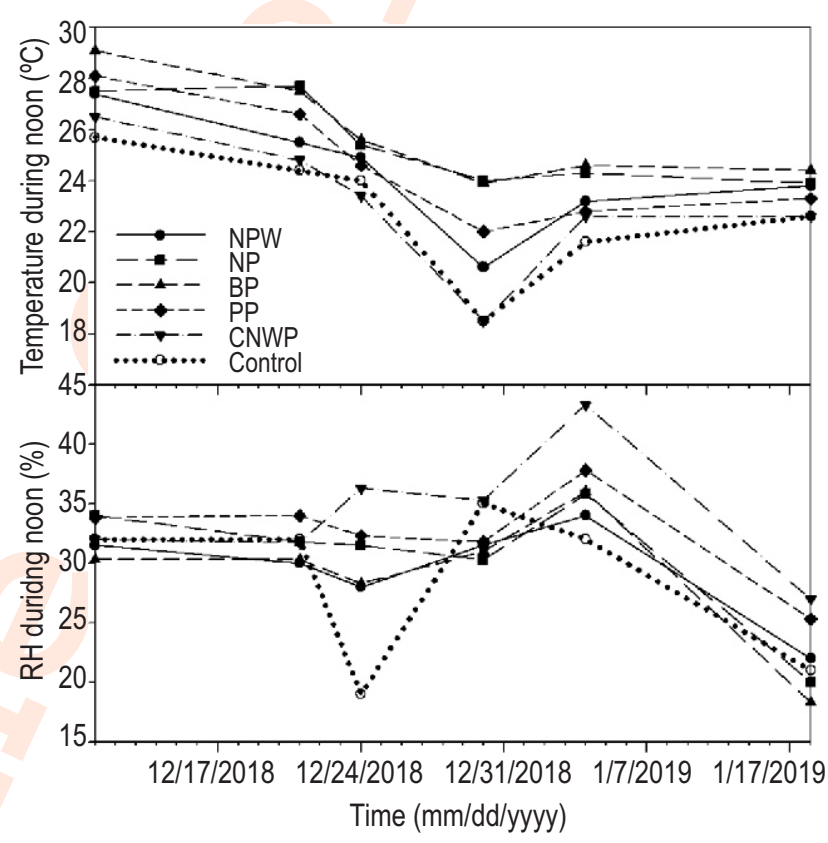

Fig. 1 : Temperature and relative humidity inside bagging conditions during fruit growth period of pomegranate $\mathrm{cv}$. Bhagwa in arid conditions during 2018-2020 (December-January).

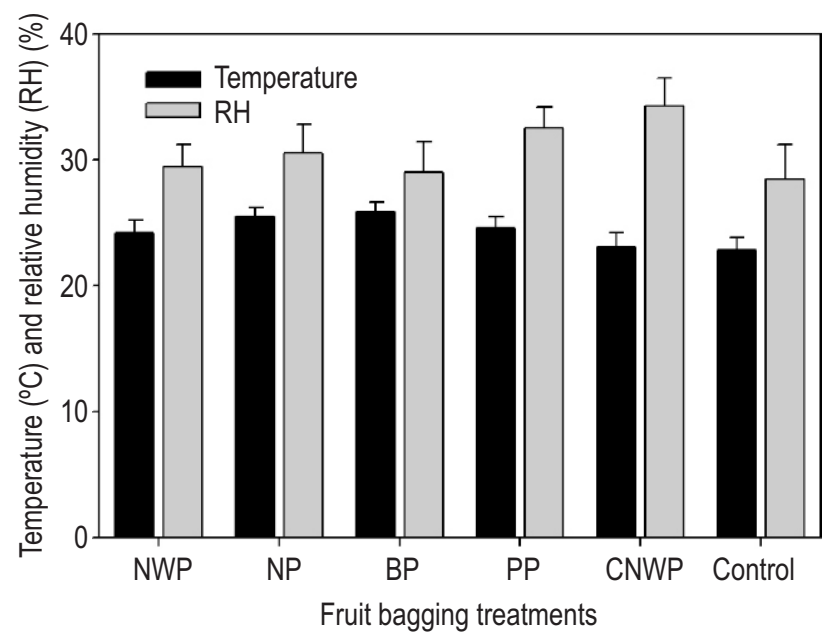

Fig. 2 : Average temperature and relative humidity inside fruit bagging materials during fruit growing period of pomegranate $\mathrm{cv}$. Bhagwa in arid conditions during 2018-2020 (December-January). 
Table 2: Effect of fruit bagging and plant covers on colour of pomegranate cv. Bhagwa in arid conditions during 2018-2020

\begin{tabular}{|c|c|c|c|c|}
\hline \multirow[t]{2}{*}{ Fruit bagging treatments* } & \multicolumn{3}{|c|}{ "Colour paremeters of CIEL*a*b* colour space model } & \multirow[t]{2}{*}{ Chroma (C) } \\
\hline & $L^{*}$ & $a^{*}$ & $\mathbf{b}^{*}$ & \\
\hline NWP & $71.4^{\mathrm{a}}$ & $39.6^{\mathrm{a}}$ & $10.5^{\mathrm{a}}$ & $41.45^{\mathrm{a}}$ \\
\hline NP & $75.9^{b}$ & $31.9^{b}$ & $7.6^{\mathrm{b}}$ & $32.29^{b}$ \\
\hline $\mathrm{BP}$ & $77.1^{\mathrm{b}}$ & $31.2^{\mathrm{b}}$ & $9.8^{\mathrm{a}}$ & $31.53^{\mathrm{b}}$ \\
\hline PP & $73.0^{\mathrm{a}}$ & $44.4^{\mathrm{c}}$ & $7.1^{\mathrm{b}}$ & $44.0^{\circ}$ \\
\hline CNWP & $69.9^{\mathrm{a}}$ & $36.6^{\mathrm{a}}$ & $11.2^{\mathrm{c}}$ & $38.02^{\mathrm{a}}$ \\
\hline Control & $65.8^{c}$ & $28.1^{\mathrm{d}}$ & $13.2^{\mathrm{c}}$ & $31.47^{b}$ \\
\hline
\end{tabular}

(Super scripted letters above values represents similarity and dissimilarity; values with similar letters are statistically similar whereas values with dissimilar letters are statistically dissimilar) ${ }^{* *}$

Table 3 : Effect of fruit bagging and plant covers on physical quality attributes of pomegranate cv. Bhagwa in arid conditions during 2018-2020

\begin{tabular}{llllllll}
\hline $\begin{array}{l}\text { Fruit bagging } \\
\text { treatments }\end{array}$ & $\begin{array}{l}\text { Fruit length } \\
(\mathbf{c m})\end{array}$ & $\begin{array}{l}\text { Fruit breadth } \\
(\mathbf{c m})\end{array}$ & $\begin{array}{l}\text { Fruit weight } \\
(\mathbf{g})\end{array}$ & $\begin{array}{l}\text { Ratio of aril/ } \\
\text { fruit weight }\end{array}$ & $\begin{array}{l}\text { Ratio of rind/ } \\
\text { fruit weight }\end{array}$ & $\begin{array}{l}\text { Rind thickness } \\
(\mathbf{m m})\end{array}$ & $\begin{array}{l}\text { Juice content } \\
(\%)\end{array}$ \\
\hline NWP & $7.6^{\mathrm{a}}$ & $7.4^{\mathrm{a}}$ & $223.0^{\mathrm{a}}$ & $140.6^{\mathrm{a}}$ & $54.0^{\mathrm{a}}$ & $4.3^{\mathrm{a}}$ & $37.5^{\mathrm{a}}$ \\
NP & $6.4^{\mathrm{a}}$ & $6.9^{\mathrm{a}}$ & $214.4^{\mathrm{b}}$ & $142.2^{\mathrm{a}}$ & $56.7^{\mathrm{a}}$ & $4.4^{\mathrm{a}}$ & $31.6^{\mathrm{a}}$ \\
BP & $6.6^{\mathrm{a}}$ & $7.0^{\mathrm{a}}$ & $183.0^{\mathrm{b}}$ & $124.5^{\mathrm{b}}$ & $53.0^{\mathrm{a}}$ & $4.7^{\mathrm{b}}$ & $34.5^{\mathrm{b}}$ \\
PP & $7.5^{\mathrm{a}}$ & $6.9^{\mathrm{a}}$ & $240.2^{\mathrm{a}}$ & $158.0^{\mathrm{a}}$ & $53.3^{\mathrm{a}}$ & $3.9^{\mathrm{a}}$ & $39.6^{\mathrm{a}}$ \\
CNWP & $6.8^{\mathrm{a}}$ & $7.2^{\mathrm{a}}$ & $228.0^{\mathrm{a}}$ & $152.0^{\mathrm{a}}$ & $68.4^{\mathrm{b}}$ & $4.2^{\mathrm{a}}$ & $35.9^{\mathrm{b}}$ \\
Control & $6.8^{\mathrm{a}}$ & $7.2^{\mathrm{a}}$ & $198^{\mathrm{b}}$ & $128.7^{\mathrm{b}}$ & $74.8^{\mathrm{c}}$ & $4.7^{\mathrm{a}}$ & $32.0^{\mathrm{c}}$ \\
\hline
\end{tabular}

(Super scripted letters above values represents similarity and dissimilarity; values with similar letters are statistically similar whereas values with dissimilar letters are statistically dissimilar) ${ }^{* *}$

Table 4 : Effect of fruit bagging and plant covers on chemical quality attributes of pomegranate cv. Bhagwa in arid conditions during 2018-2020.

\begin{tabular}{|c|c|c|c|c|c|c|}
\hline $\begin{array}{l}\text { Fruit bagging } \\
\text { treatments* }\end{array}$ & $\begin{array}{l}\text { Acidity } \\
(\%)\end{array}$ & $\begin{array}{l}\text { TSS } \\
\text { (B) }\end{array}$ & $\begin{array}{l}\text { Total sugars } \\
(\%)\end{array}$ & $\begin{array}{l}\text { Ascorbic acid } \\
\left(\mathrm{mg} 100 \mathrm{ml}^{-1}\right)\end{array}$ & 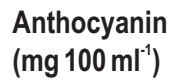 & $\begin{array}{l}\text { Total phenols } \\
\text { (mg catechol equi.ml } l^{-1} \text { ) }\end{array}$ \\
\hline NWP & $0.48^{a}$ & $16.2^{\mathrm{a}}$ & $14.0^{\mathrm{a}}$ & $22.2^{\mathrm{a}}$ & $7.90^{\mathrm{a}}$ & $4.07^{\mathrm{a}}$ \\
\hline NP & $0.42^{\mathrm{a}}$ & $17.0^{\mathrm{b}}$ & $13.5^{\mathrm{a}}$ & $18.45^{b}$ & $6.98^{b}$ & $3.94^{\mathrm{a}}$ \\
\hline $\mathrm{BP}$ & $0.44^{a}$ & $16.7^{\mathrm{a}}$ & $12.8^{\mathrm{a}}$ & $18.69^{b}$ & $6.20^{\mathrm{b}}$ & $3.28^{\mathrm{a}}$ \\
\hline PP & $0.52^{\mathrm{a}}$ & $17.3^{\mathrm{b}}$ & $16.9^{b}$ & $22.6^{\mathrm{a}}$ & $9.38^{\mathrm{c}}$ & $4.99^{b}$ \\
\hline CNWP & $0.46^{a}$ & $16.5^{\mathrm{a}}$ & $13.6^{\mathrm{a}}$ & $19.80^{b}$ & $7.26^{\mathrm{a}}$ & $5.17^{b}$ \\
\hline Control & $0.54^{\mathrm{a}}$ & $16.4^{\mathrm{a}}$ & $14.26^{\mathrm{a}}$ & $18.80^{b}$ & $6.24^{\mathrm{b}}$ & $3.72^{\mathrm{a}}$ \\
\hline
\end{tabular}

(Super scripted letters above values represents similarity and dissimilarity; values with similar letters are statistically similar whereas values with dissimilar letters are statistically dissimilar) ${ }^{* *}$

transmission pattern of each bag in the visible, far red and /or infra-red regions of the spectrum (Sharma et al., 2014). Our result is in agreement with the findings of Asresy et al. (2019) and Sharma et al., (2014), while Hamedi et al. (2019) did not find any significant effect of bagging on $a^{*}$ (redness) and $C^{*}$ (colour intensity) value in pomegranate.

Individual fruit bagging and plant covering with nonwoven polypropylene showed no significant effect on the size of fruit, though the length and breadth were slightly higher in nonwoven polypropylene bagging. Parchment paper bagging and non-woven polypropylene bagging or covering showed significantly higher fruit weight than other treatments. The weight of arils per fruit was also influenced significantly by bagging over control, except brown paper bagging. Different bagging and plant covering, except brown paper bagging, yielded low weight of peel per fruit than control. Similarly, thicker peel was found in brown paper bags and un-bagged fruit than other bagging treatments. The results of the present study are similar with the observations reported by Oren-Shamir (2009) that the plant cuticle thickness reduced in low light intensity and high moisture prevalence in growing environment. Decrease in peel thickness and peel weight in bagged fruit may be due to high humidity inside bags, which could have affected cell structure, configuration and cuticle thickness. Amarante et al., (2002) and Asrey et al., (2019) also reported on similar line that the decrease in peel thickness as a 
result of bagging could be due to the low light intensity and high humidity inside the bag, which can affect the cell structure, peel elasticity and peel thickness. Bagging of fruits exhibited variable effect on juice content. Among bags parchment paper and nonwoven polypropylene bagging yielded significantly higher juice content while news paper bags and un-bagged fruits recorded lesser juice content. The obvious reasons for higher juice recovery pattern in different treatment may be attributed to aril weight, peel weight and thickness as evident from the data presented in Table 3. Parchment paper and non-woven polypropylene bagging had higher aril weight and low peel weight with thinner peel.

Individual fruit bagging and plant covering with nonwoven polypropylene showed no significant effect on acidity of juice (Table 4). Though, acidity was found slightly higher in unbagged fruits but total soluble solids was significantly influenced by parchment paper and news paper bagging. Similarly, total sugar content was also not significantly influenced by bagging or plant covers, except parchment paper bagging. Since Mrig bahar cropping season is retained in arid western Rajasthan, the maximum organoleptic characters in fruits was developed during December onwards. During this period, there is sharp fluctuations in environmental conditions, especially temperature, sun light and humidity. As evident from the data (Fig 1,2), white colour parchment paper had relatively constant optimum temperature and humidity inside bags, which might be due to optimum light reflectance, absorbance and transmittance. Work carried out by various workers (Muhammad et al., 2021; Sharma et al., 2014; Lin et al.,2012; Ni et al., 2010 on influence of bagging on the development and quality of different fruit crops concluded that bagging materials, bagging time, colour of bags, stage of fruit growth etc resulted variable effects on physico-chemical quality of fruits.

Fruit covered with white parchment paper and non-woven polypropylene bags had higher ascorbic acid content than other bagged or un-bagged fruits (Table 4). However, bagging and row covering had clear effect on total anthocyanin value of fruit juice. Bagging with parchment paper bags showed highest content followed by non-woven polypropylene bagging or plant covering. Plants covered with non-woven polypropylene had highest total phenols at par with white parchment paper bagging. Un-bagged fruit and brown paper bagging showed minimum total phenols in fruit juice. Both the ascorbic acid and phenols are heat labile phyto-nutrients (Borochov-Neori et al., 2011). Penetration of photosynthetically active radiation (PAR) inside the bag may be the probable reason for higher ascorbic acid content and total phenols in white parchment paper and non-woven polypropylene bags as higher transmittance of PAR were recorded in present study. Chonhenchob et al. (2011) also correlated higher content of these phyto-nutrients and sun light permeability in red colored bags. The variable effects of different bags and covering on total anthocyanin content of fruit juice may be due to difference in light reflectance, absorbance, or transmission pattern of each bag (Chonhenchob et al., 2011). It clearly corroborates with the results of PAR and, temperature and humidity inside bags (Fig. 1, Fig. 2) in the present study that white parchment paper bags had highest PAR followed by non-woven polypropylene. Findings of our study is in agreement with the findings of Oren-Shamir (2009) and Schwartz et al.,(2009) who also reported the role of fruit bagging on anthocyanin content by the alteration in level of radiation, intensity of sunshine and exposure of fruits to sun light.

In conclusion, the modification caused by white parchment paper or non-woven polypropylene bags provided favourable microclimate for superior quality fruits of pomegranate. Thus, bagging is a simple, cost-effective and ecofriendly technique to produce quality safe pomegranate fruits under adverse climatic conditions of arid regions.

\section{Acknowledgments}

The authors acknowledge the financial support rendered by the National Bank for Agriculture and Rural Development (NABARD). The authors are also thankful to the Director, ICARCentral Arid Zone Research Institute, Jodhpur for providing facilities.

\section{Add-on Information}

Author's contribution : A. Singh: Conceptualization, experimentation, original draft preparation; H.M. Meena: Meteorological observations, tabulation and interpretation; P. Santra: Statistical analysis, tables, Figures; P.R. Meghwal: Review and editing; P. Kumar: Data recording, editing.

Research content: The research content of manuscript is original and has not been published elsewhere.

Ethical approval: NotApplicable.

Conflict of interest: The authors declare that there is no conflict of interest.

Data from other sources: NotApplicable.

Consent to publish: All authors agree to publish the paper in Journal of Environmental Biology.

\section{References}

A.O.A.C., Official Methods of Analysis (17 Edn.). Association of Official Analytical Chemist, Washington, DC (2000)

Amarante, C., N.H. Banks and S. Max: Effect of preharvest bagging on fruit quality and post harvest physiology of pear (Pyrus communis). New Zealand J Crop Hort Sci., 30, 90-107 (2002)

Asrey R., K. Kumar, R.R. Sharma and N.K. Meena: Fruit bagging and bag color affects physico-chemical, nutraceutical quality and consumer acceptability of pomegranate (Punica granatum L.) 
arils. J. Food Sci. Technol., 57, 1469-1476 (2019)

Babu, K.D.: Floral biology of pomegranate (Punica granatum L.) In: Pomegranate (Ed.: R. Chandra). Fruit Veg. Cereal Sci. Biotechnol., pp. 45-50 (2010)

Borochov-Neori, H., S. Judeinstein, M. Harari, I. Bar-Ya'Akov, B.S. Patil, S. Lurie and D. Holland: Climate effects on anthocyanin accumulation and composition in the pomegranate (Punica granatum L.) fruit arils. J. Agric. Food Chem., 59, 5325-5334 (2011)

Chonhenchob, V., D. Kamhangwong, J. Kruenate, K. Khongrat, N. Tangchantra, U. Wichai and S.P. Singh: Preharvest bagging with wavelength-selective materials enhances development and quality of mango (Mangifera indica L.) cv. Nam Dok Mai. J. Sci. FoodAgri., 91, 664-671 (2011).

Gadze, J., S.C. Voca, Z. Melik, I. Mustac, S. Ercisli and M. Radunic: Physico-chemical characteristics of main pomegranate (Punica granatum L.) cultivars grown in Dalmatia region of Croatia. J. App. Bot. Food Qual., 85, 202-206 (2012).

Grinan, I., D. Morales, A. Galindo, A. Torrecillas, David, P. Lopez, A. Moriana, J.C. Gonzalez, A. A-Carbonell and F. Hernandez: Effect of preharvest fruit bagging on fruit quality characteristics and incidence of fruit physiopathies in fully irrigated and water stressed pomegranate trees. J. Sci. FoodAgri., 99, 1425-1433 (2018).

Gumienna, M., A. Szwengiel and B. Gorna: Bioactive components of pomegranate fruit and their transformation by fermentation process. European Food Res. Tech., 242, 631-640 (2016).

Hamedi F.S., F. Moradinezhad and K. Mehdi: Pre-harvest bagging influences sunburn, cracking and quality of pomegranate fruits. $J$. Horti. Postharvest Res., 2, 131-142 (2019).

Han J.H., K.H. Hong, H.I. Jang, I.H. Jo, J.J. Choi and H.J. Lee: Effect of characteristics of the bags and microclimate in the bags on russet of 'Whangkeumbae' pear fruit. Korean J. Hort. Sci. Techno., 20, 3237 (2002).

Kim, Y.H., S.C. Lim, C.K. Youn, B.A. Lee, T. Youn, T.S. Kim and J.M. Park: Effects of physical properties of bagging papers and changes of microclimate in the bags on coloration and quality of peach fruits. $J$. Korean Soci. Horti. Sci., 44, 483-488 (2003).

Kim, Y.K., S.S. Kang, K.S. Cho and S.B. Jeong: Effects of bagging with different pear paper bags on the color of fruit skin and qualities in " Manpungbae". Kor. J. Hortic. Sci. Technol., 28, 36-40 (2010).

NHB: Horticultural Statistics at a Glance 2018. Department of Agriculture, Cooperation and Farmers Welfare, Ministry of Agriculture and Farmers Welfare, Government of India, New Delhi (www.agricoop.nic.in) (2018).

Lin, J., J.H. Wang, X.J. Li and Y.H. Chang: Effects of bagging twice and room temperature storage on quality of Cuiguan' pear fruit. Acta Horti., 934, 837-840. (2012).

Muhammad, M. A., R. Anwar, A. F. Yousef, B. Li , A. Luvisi, L. D. Bellis, A. Aprile and $F$. Chen: Influence of bagging on the development and quality of fruits. Plants, 10, 358-374 (2021).

$\mathrm{Ni}, \mathrm{Z}$., Z. Zhang, L. GaoZ, Gu and L. Huang: Effects of bagging on sugar metabolism and the activity of sugar metabolism related enzymes during fruit development of 'Qingzhong' loquat. African J. Biotech.
$10,4212-4216(2010)$

Oren-Shamir, M.: Does anthocyanin degradation play a significant role in determining pigment concentration in plants. Plant Sci., 177, 310-316 (2009)

Ram Chandra, S., Suroshe, J. Sharma, R.A. Marathe and D.T. Meshram: Pomegranate growing manual. NRC on Pomegranate, Solapur, pp. 58 (2011).

Ranganna, S.: Handbook of Analysis and Quality Control For Fruit and Vegetable Products. Tata McGraw-Hill Education Publication, New Delhi, 1112 pages (2017).

Sarkomi, F.H., F. Moradinezhad and M. Khayat: Pre-harvest bagging influences sun burn, cracking and quality of pomegranate fruits. $J$ Horti. Post Harv. Res., 2, 131-142 (2019).

Schwartz, E., R. Zulker, I. Glazer, I. Bar-Ya'Akov, Z. Wiesman, E.I. Tripler, Bar-llan H. Fromm, H. Borochov-Neori, D. Holland and R. Amir: Environmental conditions affect the color, taste and antioxidant capacity of 11 pomegranate accessions fruits. J. Agric. Food Chem., 57, 9197-9209 (2009).

Sharma, R.R., R.K .Pal, V.R. Sagar, K.K. Parmanick, V. Paul, V.K. Gupta and M.R. Rana: Impact of pre-harvest fruit-bagging with different coloured bags on peel colour and the incidence of insect pests, disease and storage disorders in 'Royal Delicious' apple. The $J$. Horti. Sci. Biotech., 89, 613-618 (2014).

Sharma, R.R., R.K. Pal, R. Asrey, V.R. Sagar, M.R. Dhiman and M.R. Rana: Pre-harvest fruit bagging influences fruit color and quality of apple cv. Delicious. Agric. Sci., 9, 443-448 (2013).

Singh, A., P.R. Meghwal and P. Kumar: Quality pomegranate from thar desert. Indian Horticulture, 64, 29-32 (2019a).

Singh, A., U. Burman, P. Santra, A. Saxena and P.R. Meghwal: Relationship of plant water status and leaf gas exchange with fruit cracking of pomegranate. Ind. J. Hort., 76, 289-293 (2019b)

Singleton, V.L., R. Orthofer and R.M. Lamuela-Raventos: Analysis of total phenols and other oxidation substrates and antioxidants by means of Folin-Ciocalteu reagent. Methods Enzymol., 299, 152178(1999)

Supe, V.S. and Y.S. Saitwal: Morphological, biochemical and qualitative changes associated with growth and development of pomegranate fruit (Punica granatum L.). Indian J. Agric. Res., 50, $80-83(2016)$

Xu, H.X., J.W. Chen and M. Xie: Effect of different light transmittance paper bags on fruit quality and antioxidant capacity in loquat. $\mathrm{J}$. Sci. FoodAgric., 90, 1783-1788 (2010).

Yang, W.H., X.C. Zhu, J.H. Bu, G.B. Hu, H.C. Wang and X.M. Huang: Effects of bagging on fruit development and quality in cross-winter off-season longan. Scie. Horticul., 120, 194-200 (2009).

Yuan, Z.H., Y.L. Yin, L.J. Feng, X.Q. Zhao, L.F. Hou and Y.X. Zhang: Evaluation of pomegranate bagging and fruit cracking in Shandong, China. Acta Horticulturae, 940,125-130 (2012).

Zhang, B.B., J.Y. Guo, R.J. Ma, J.X. Cai, J. Yan and C.H. Zhang: Relationship between the bagging microenvironment and fruit quality in 'Guibao' peach [Prunus persica (L.) Batsch]. J. Hort. Sci Biotech., 90, 303-310 (2015). 